\title{
Disconnectivity Social of Conflict in the Circle of Iron Ore Mine in Bone Regency, South Sulawesi, Indonesia
}

\author{
Andi Illham Samanlangi ${ }^{1,}$, Andi Agustang ${ }^{1}$, Arlin $^{*} \mathrm{Adam}^{2}$ and Andi Alim $^{2}$ \\ ${ }^{1}$ Department of Sociology, University of State Makassar, Makassar City, South Sulawesi, Indonesia \\ ${ }^{2}$ Department of Public Health, University of Pejuang Republik Indonesia, Makassar City, South Sulawesi, \\ Indonesia
}

\begin{abstract}
Conflict is a common occurrence in mining activities that ignore the triple bottom line principle. Neglecting the impact of environmental damage and the welfare of the communities around the mine has resulted in social disconnection leading to conflict. This study aims to describe comprehensively the social disconnect in the iron ore mining project in Bontocani District so that mining conflicts do not occur. The research method used is a mixed-method with a sequential design starting with qualitative methods then followed by quantitative methods. The findings of this study indicate that the causes of social disconnect include: There are environmental impacts that damage the livelihoods of residents around the mine area, the company does not respect local wisdom, the role of government is not maximal as a mediator, The economic impact is in the form of loss of livelihoods in the agricultural sector which is exacerbated by road infrastructure. damaged and Social impact in the form of jealousy between residents. The practical implication of this research is the creation of a harmonious relationship between the government, companies and communities in mining management.
\end{abstract}

Keywords: Disconnectivity social, triple bottom line, conflict.

\section{INTRODUCTION}

Mining activities are activities that in some cases cause conflicts between communities and companies. The Mining Advocacy Network in its early 2020 records and the projection of the Mining Advocacy Network recorded that between 2014-2019 the area of conflict surrounding the mine was 925,748 hectares. The extent of the conflict area involved 71 cases of conflict with details of 23 cases of coal mining conflicts, 23 cases of gold, 11 cases of iron sand, and 5 cases of nickel. Even in its report, the Mining Advocacy Network (2020: II) states that 3,092 coal mine pits are still gaping, containing toxic water and containing dangerous heavy metals. Victims who have fallen from the records of the Mining Advocacy Network have reached 143 lives, the majority of victims are still children, there have been many reports and even discussions covering this issue (Jamil and Reffelsen 2020).

The data above shows that mining activities that are mismanaged can hurt the community. As a result, people will fight back to demand improvements for their lives. At this point, the occurrence of social disconnect is suspected to be the main determinant of social conflict around the mine.

*Address correspondence to this author at the Departemen of Sociologi, University of State Makassar, JI. A. P. Pettarani, Tidung Vilage, Rappocini Distrik, Makassar City, South Sulawesi 90222, Indonesia;

E-mail: andhis1971@gmail.com
Social discretion begins with a disharmonious relationship between the community and the company. Where subordinate and marginalized groups begin to understand well the roots of operations against them. The effects of mining activities that are detrimental to the community will of course lead to counter resistance. This can be identified by researchers from preliminary observations of iron ore mining in Bontocani District.

Mining management in this area has triggered a conflict which was manifested by several community demonstrations that have occurred since 2011 until now. Demonstrations by residents show that there is dissatisfaction with various problems including land acquisition problems, mining road problems, environmental quality degradation due to iron ore mining activities, especially damage to agricultural land and community plantations as well as disruption of water sources and the recruitment of local workers in ore mining activities. iron by PT Sindo Mandiri, PT MMI, PT Anugrah Permata Bumi (APB) and PT Bumi Sulawesi Mineral (BSM) in Bontocanni District, Bone Regency.

The researchers' preliminary observations indicated that mining activities, again, created a conflict that harmed not only the community but the company itself. Mining companies should have a natural resource management paradigm that balances the 3 dimensions of Planet-Profit-People. The balance in the management of the planet (environment), profit (company profit), and people (society) will bring encouraging results for all parties. However, in reality, 
mining management is too heavy towards profit and ignores other dimensions, especially the building of communication among stakeholders

Ignorance of communication among stakeholders results in social disconnectivity. The occurrence of social disconnectivity was marked by conflict between various elements in society. Social disconnectivity does not only occur between companies and the community. Social disconnectivity also occurs between elements in society which create horizontal conflicts. Also vertical conflicts between communities and local governments and companies and local governments.

Therefore, this study aims to uncover the phenomenon of social discretion in the mining environment in the hope that potential conflicts that harm all parties will not occur. In addition, it is hoped that the results of this study will recommend intellectual-theoretical directions that can be used as a reference in improving the harmonious relationship pattern among mining actors.

\section{LITERATURE REVIEW}

\section{Three Key Elements as the Basis for Mining Activities}

Mining activities are activities that not only change the landscape of the earth's surface which causes degradation of the carrying capacity of the environment but also have the potential to affect the social cohesiveness of the affected people. Mining activities are not a little faced with environmental problems but also against residents' resistance. The root of social distanceoccurs due to social discontinuity between groups in society.

Social conflict is the result of social disconnect. In mining activities, the conflict between companies and residents is something that sometimes happens. The conflicts can vary. Widyanta (2013) noted 6 conflict models in mining activities: "Conflict can be mapped into 6 elements: first, the social conflict between indigenous people and migrant residents; second, citizen competition in accessing jobs, infrastructure and natural resources; third, citizens' feelings of inequality in treatment; fourth, differences in income and the accumulated welfare of citizens; fifth, competition and social jealousy among the community; and sixth, community mining and resource conflicts. The six problems have surfaced as a complex and interwoven social phenomenon".
Conflict variants in mining activities can be prevented by anticipating social disconnect. Preventing social disconnect requires that mining activities are expected to not only pay attention to the profit factor as the only consideration. Consideration of people (sociology) and planet (environment) is absolutely necessary, not only ideal on paper but problematic in implementation. In other words, every company activity must consider two factors, namely financial and nonfinancial factors.

The Triple Bottom Line concept is a concept that can describe the proper management of mining activities. This concept has advantages in measuring economic, ecological factors and the effects of industrial activity on society. John Elkington in Arowoshegbe, Emmanuel, and Gina (2016) states that "Sustainable development involves the simultaneous pursuit of economic prosperity, environmental quality, and social equity. That companies aiming for a sustainability need to perform not against a single, financial bottom line but against the triple bottom line".

Ignorance of the triple bottom line principle has the potential to create social disconnect among mining activity stakeholders. The emergence of social disconnect has triggered conflicts that were latent to manifest. A conflict that occurs by itself will harm all parties.

Research conducted by Irwandi and Chotim (2017) found that social disconnectedness leads to conflict. The conflict that occurred in Sungai Samak Hamlet, Sungai Samak Village, Badau District, Belitung Regency was motivated by various factors, ranging from the absence of socialization, the lack of openness of the village government to the community, the difference in the importance of the impact caused by mining activities. The form of conflict that occurred in Sungai Samak Hamlet, Sungai Samak Village, Badau District, Belitung Regency was vertical conflict and horizontal conflict. Vertical conflict occurs between the community, village government and mining companies. Meanwhile, horizontal conflicts occur within society itself between pro and contra groups. Conflict resolution efforts were undertaken by the community, government and mining companies include negotiating; Consolidation; Mediation; and lastly Arbitration. At the arbitration stage, the public lawsuit was rejected by the Tanjung Pandan District Court, as was the decision at the appeal level. However, after the appeal decision was issued, the company suddenly stopped their mining activities in Sungai Samak Hamlet. 
The facts above show that there is a social disconnect which results in cohesiveness between stakeholders in torn mining activities. Social cohesiveness is a very valuable asset in knitting cooperation between stakeholders in mining activities. Social disconnect, psychologically, can trigger interpersonal dysfunctional behaviour. Lee, Draper, and Lee (2001) state that "For most people, a lack of belonging in life is a temporary, unpleasant experience that is overcome by reappraising relationships, mending friendships, seeking new social bonds, and participating in social activities. These people never feel fully disconnected from society as a whole and can make appropriate interpersonal changes in their lives to re-establish a sense of belonging". Widespread psychological problems as a result of social disconnect will trigger social problems, namely conflict.

The antithesis of social disconnect is social connectivity. Social connectivity is defined by EraslanCapan (2016) as a person's deep understanding of how close they are to other people in the sphere of their social world. Incorrect mining governance can tear social connectivity in the community.

In other words, the existence of social disconnect is a signal of neglect of the Triple bottom line principle. This concept contains 3 elements which Firouzeh, Jay, and Grant (2017) explain as follows: 1) Profit: Economic dimension of sustainability - emphasizes increasing output value, while reducing input value, thus maximizing profit, revenue, and economic growth. Such growth should also be aligned to environmental and social benefits; 2) Planet: Environmental dimension of sustainability - encourages organizations to reduce (or at least minimize) their negative environmental impacts and to actively contribute to green practices, such as natural resources protection, waste collection, pollution prevention, etc; and people: Social dimension of sustainability - supports the development of programs related to social welfare and stakeholders' satisfaction. Often overlooked in the literature, this dimension lacks broad consensus on analyzing impacts.

Avoiding social disconnection among mining stakeholders means understanding that the benefits obtained by the company must go hand in hand with concern for the environment and the welfare of the people around the mine area. Smith and Sharicz in Felisia and Limijaya (2014) state that: "The result of the activities of an organization voluntary or governed by law, that demonstrates the ability of the organization to maintain viable its business operations (including financial viability as appropriate) whilst not negatively impacting any social or ecological systems". The three elements above can be described by Kambewa (2007) as follows:

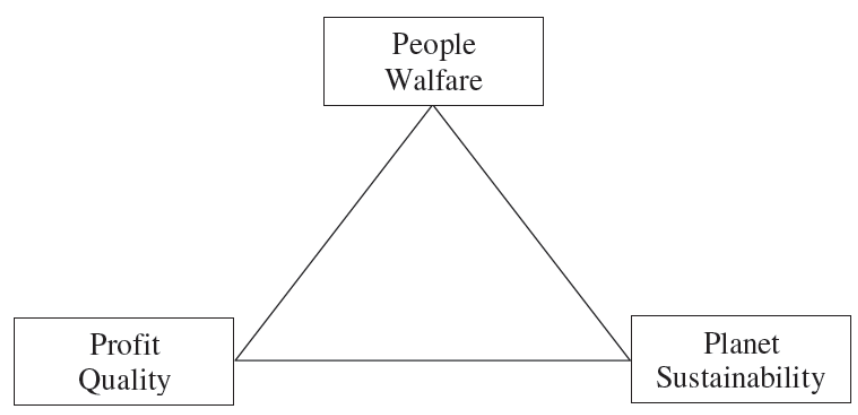

Figure 1: Sustainable development model.

The picture above shows the absolute requirement for sustainable development to determine the extent to which the company can balance the three elements above. Ideally, profits can be maximized while still paying attention to the production process so as not to cause environmental damage and ignore the welfare of the community.

\section{Social Disconnectivity Theory}

Social disconnectivity theory seeks to observe conflictual relationships between stakeholders. Conflictual relations in the implementation of the mining process result in social disconnectivity. In preliminary observations, a conflictual relationship was found in the iron ore mining area in Bontocani District, as follows:

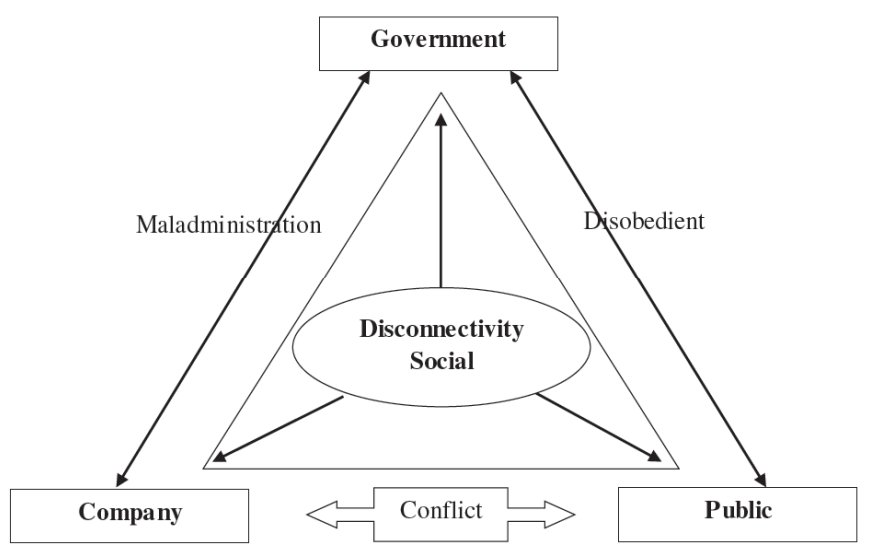

Figure 2: Social Disconnectivity.

Social disconnectivity according to Cornwell dan Waite (2009) is defined as: "Social disconnectedness, marked by a lack of social relationships and low levels of participation in social activities, and perceived isolation, defined by loneliness and a perceived lack of 
social support". Due to a lack of social relations and a low level of participation in social activities, previously latent conflicts will manifest in the public sphere. Social disconnectivity shows that individuals or groups in society negate each other, which is possible because of differences in interests.

Social discretion in the mining circle occurs in 3 relationship patterns, namely 1 . the relationship between the government and the company due to maladministration, 2. The relationship between the government and the community due to community noncompliance with applicable regulations, and the relationship between the company and the community due to the conflict that occurs. predominantly caused by agrarian conflicts.

The event of social disconnect among mining actors will subsequently have consequences for the welfare of the community and on environmental balance, including losses for the potential benefits of the company. In short, social disconnect leads to losses for all parties.

The phenomenon of social disconnect can be seen in Qurbani (2020) research on iron sand mining conflict in Lumajang, which finds the root of the conflict problem, namely: "Conversion of agricultural land into mining areas occurs so much that it harms farmers because agricultural land is decreasing. Environmental degradation is very fast ". Changes in land use cause farmers to no longer have long-term economic capital to support them. Moreover, mining activities also cause environmental damage. This kind of situation will automatically create conditions for the social disconnect that lead to conflict.

The social discontinuity can tear social integration in social life. The entry of mining companies can trigger social disconnect. Munauwarah (2016) researched in the area of Ledu-Ledu Village and found social conflicts that occurred between the company and the local community. The results of his research found that "The conflict between indigenous peoples and PT. Vale Indonesia happened because of PT. Vale Indonesia has occupied the land of the indigenous people of To Karunsi'e, which has turned the land of indigenous peoples into a golf course. Meanwhile, these indigenous people are always called illegal residents. Mediation conducted by the local government and PT. Vale Indonesia has been done several times, but it never produced results. This is caused by the desire of the government and PT. Vale Indonesia so that the
Karunsi'e indigenous people leave their customary location and want to be relocated to Wasuponda, LeduLedu Village "

Theoretically, the phenomenon of social disconnect will lead to social isolation at both the individual and group levels. Social isolation can be described as a state of lack of interaction between individuals and groups of people for various reasons. Eckhard (2021) states "Social isolation is commonly understood as the absence or as a lack of social contact or social relations". The lack of social contact and interaction is a sign of social disconnect in society. Cornwell and Waite (2009a) added: "Social disconnectedness can be characterized by a lack of contact with others and indicated by situational factors, such as a small social network, infrequent interaction, and a lack of participation in social activities and groups".

Social discretion is the root of the marginalization of subordinate groups by the dominant group. Marginalization will lead to social isolation that makes subordinate groups unable to get what they are entitled to. This study seeks to detail various indicators of the causes of social disconnect and measure its depth. Guilcher et al. (2021) very carefully conclude in their research that "Findings reinforce the complexity of social disconnectedness and the importance in understanding the various indicators of social disconnectedness as they relate to social isolation".

\section{RESEARCH METHODS}

This research method uses the Mix Method research. The Mix Method has a different philosophical basis. If the quantitative method is based on the positivism paradigm and the qualitative method is based on the positivism paradigm, the mixed method has a different philosophical foundation. Even though it combines quantitative and qualitative methods, it does not mean that the mixed method also combines its philosophical basis, which is very unlikely. The mixedmethod has its philosophical basis, namely pragmatism. Creswell \& Clark (2017) stated that the main reason for using a combination of qualitative and quantitative approaches is to provide a better understanding of the research problem than using a single approach.

The mix method is an alternative variant that has long been known. Created to seek a synthesis of contradictions Tashakkori, Teddlie, and Teddlie (1998) state that the history of mixed methods research has 


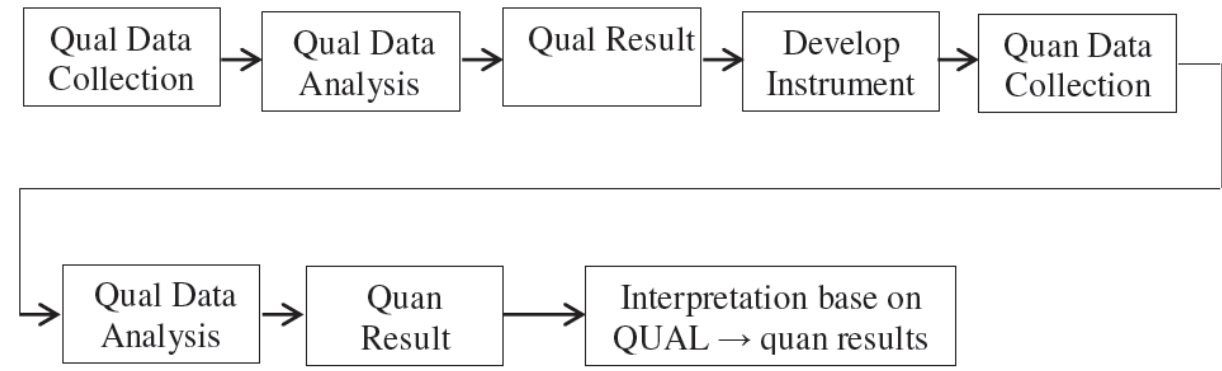

Figure 3: Stages of the Mix Method Exploratory Design Research.

been developed during the Campbell and Fiske era in 1959 to the time of Johnson and Onwuegbuzie in 2004 and tries to position mixed methods research as a complement to traditional research. previously, the qualitative and the quantitative which lasted for centuries could not be reconciled with one another. The presence of mixed methods research is a new paradigm that seeks to find common ground and overcome disputes from the two previous research methods.

The mixed-method research design in this study is exploratory. Greene, Caracelli, and Graham (1989) explain that exploratory research design is a mixedmethod research design which is the result of the first (qualitative) research method which can help develop or inform the second (quantitative) method.

This research method uses Mix Method exploratory design research, which is a combination of qualitative and quantitative methods, where qualitative methods are used to carry out concept taxonomy and quantitative methods are used to verify and test propositions generated in qualitative methods (Creswell and Clark 2017).

The exploratory design of the mix method approach is detailed in the image above:

Figure 3 describes the stages of the mixed method which begins with the collection of qualitative data to find a taxonomy of concepts. Qualitative data were collected through in-depth interviews with selected informants using the purposive sampling technique, namely the selection of informants who were directly involved in mining work. The qualitative data found were analyzed using taxonomic techniques, namely finding the concepts that operate in the problem of disconnection. These taxonomic results are made in the form of propositions/hypotheses which are then used as the basis for developing instruments for testing quantitative data.
When testing quantitative data simultaneously qualitative analysis was also carried out to obtain an explanation of the meaning of the findings in the form of quantitative data. The combination of quantitative and qualitative data analysis is then interpreted as the final result of the research.

\section{RESULTS AND DISCUSSION}

This study found that the social relationship among the iron ore mining stakeholders in Bontocani District is dissociative. This pattern creates social disconnectivity between the community and the company. When observing the information of the informants above, the information of the informants can be calcified based on their conflictual relationship with the company. Conflictual relations by researchers are divided into 2 levels, namely high and low. High conflictual relationships are characterized by the perception of informants who believe the company is detrimental to them and low conflictual relationships are characterized by the perception that the company has benefited them as follows:

\section{The Level of Conflictual Relations}

The level of conflictual relations in the high category is described in the results of interviews with informants as follows:

"...in Bontocani it is a bit detrimental to the community..." (HA)

"...the company approached but was not right on target..." (BS)

"...Company activities are detrimental to society..." (BB)

“....Mining carried out by PT. Sindo Mandiri is more disadvantaged and shows their ignorance..." (Hu) 
"...The losses are more pronounced. The losses incurred by the company are likely to have an environmental impact..." (Nj)

"...The most dangerous disadvantages are that the excavation distance from residents' houses is only about 30 meters, the noise of heavy equipment and chemical impacts threatens the health of residents..." (NI)

"...In general, the positive impact of the mine's presence has not been felt. Not yet by the proper and correct mining concept..." (Su)

"...The losses are more pronounced in the environmental impact. Damage to community land that has been mined can no longer be used (humus soil has disappeared). Until the time the mine closed, there were more conflicts. There was no progress from resolving the conflict..." (Th)

“...Companies tend to ignore the results of collective agreements. Benefits felt only to some residents. The intended benefit is labor recruitment. However, on the other hand, the recruitment created a new conflict because not all communities around the mine (Pake hamlet and Soppo hamlet) were empowered. Then arose conflicting groups..." (Sp)

Informants who stated that the level of conflictual relations was in a low category as quoted from the following interview:

"... There is absolutely no loss caused by the company..." (HT)

"...Talking about the benefits and disadvantages, I think there are more benefits than disadvantages..." (RKT)

"...We have experienced many benefits with the company, including repairing road infrastructure, recruiting workers, and compensating the felled plants..." (RKP)

The conflictual relationship between the company and the community in the perspective of the informants illustrates a diversity of perspectives. HT, RKT, and RKP are informants that researchers think to give positive assessments. Of course, these three informants have a level of closeness to the company.

The farther the informant's level of closeness to the company, the more negative the perception and the opportunity to conflict with the company. The closer the level of closeness to the company, the more likely this informant is to collaborate with the company. The complexity of social relationships around the mine in Bontocani District can be seen from the relationship formations that have been disclosed by the informants above.

Within the framework of the Habermasian Critical Theory, conflict indicates a process of oppression. Conflicts around the mine to some degree are the result of relationships that subordinate a group of people. Bernstein in Iwan (2016) states: "The entire Habermas project leads to human liberation from all forms of oppression, including even if the oppression is carried out in and in the name of 'modern rationality'.

\section{Depth of Social Disconnectivity}

This study also found quantitative data which can be described in the following Table 1:

Based on the table below. The mining activity of iron ore caused unrest among residents. The results of the respondents showed that 8 respondents strongly disagreed, 39 disagreed, 42 agreed and 12 strongly agreed. The result of the formula index is $64.36 \%$, which is in the "Agree" category. These results indicate that the majority, namely 54 respondents, agreed that iron ore mining activities caused unrest among residents. This fact is confirmed by the index formula value of $64.36 \%$ which is a sign that the results are correct and factual.

The mining activity of iron ore has caused tension between residents. The results of the respondents showed that 5 respondents strongly disagreed, 41 disagreed, 45 agreed and 10 strongly agreed. The result of the formula index is $64.85 \%$, which is in the "Agree" category. These results indicate that the majority, namely 55 respondents, agreed that iron ore mining activities caused tensions between residents. This fact is confirmed by the index formula value of $64.85 \%$ which is a sign that the results are correct and factual.

The community often gets terror from the company. The results of respondents showed that 20 respondents strongly disagreed, 46 disagreed, 30 
Table 1: Depth Activities of Social Discrimination in Communities in the Mining Circle, Bontocani District, Bone Regency, South Sulawesi, Indonesia

\begin{tabular}{|c|c|c|c|c|c|c|c|c|}
\hline \multirow{2}{*}{ Activity Description } & \multicolumn{4}{|c|}{$\begin{array}{l}\text { Respondents' Answers } \\
\text { Frequency and Score }\end{array}$} & \multirow{2}{*}{$\begin{array}{c}\begin{array}{c}\text { Likert } \\
\text { Highest } \\
\text { Score (Y) }\end{array} \\
\text { 乏 Resp. x } 4\end{array}$} & \multirow{2}{*}{$\begin{array}{c}\begin{array}{c}\text { Total } \\
\text { Score } \\
\text { (TS) }\end{array} \\
\begin{array}{c}\sum \text { Freq x } \\
\text { Score }\end{array}\end{array}$} & \multirow{2}{*}{$\begin{array}{c}\begin{array}{c}\text { Value Formula } \\
\text { Index (\%) }\end{array} \\
(T S \times Y) \times 100\end{array}$} & \multirow{2}{*}{ Category } \\
\hline & $\begin{array}{l}\text { SD } \\
\text { (1) }\end{array}$ & $\begin{array}{l}D \\
(2)\end{array}$ & $\begin{array}{c}A \\
(3)\end{array}$ & $\begin{array}{l}\text { SA } \\
\text { (4) }\end{array}$ & & & & \\
\hline Unrest among residents & 8 & 39 & 42 & 12 & 404 & 260 & 64.36 & Agree \\
\hline Tensions Between Citizens & 5 & 41 & 45 & 10 & 404 & 262 & 64.85 & Agree \\
\hline $\begin{array}{l}\text { The community was terrorized by } \\
\text { the complete parties }\end{array}$ & 20 & 46 & 30 & 5 & 404 & 222 & 54.95 & Agree \\
\hline $\begin{array}{l}\text { The community is under threat } \\
\text { from the conflicting parties }\end{array}$ & 16 & 50 & 35 & 0 & 404 & 221 & 54.70 & Agree \\
\hline $\begin{array}{c}\text { Tensions between residents and } \\
\text { residents }\end{array}$ & 9 & 18 & 63 & 11 & 404 & 278 & 68.81 & Agree \\
\hline $\begin{array}{c}\text { Tensions between citizens and the } \\
\text { government }\end{array}$ & 6 & 30 & 61 & 4 & 404 & 265 & 65.59 & Agree \\
\hline $\begin{array}{l}\text { The community took refusal } \\
\text { actions in subtle ways/strikes }\end{array}$ & 2 & 6 & 35 & 58 & 404 & 351 & 86.88 & $\begin{array}{l}\text { Strongly } \\
\text { agree }\end{array}$ \\
\hline $\begin{array}{l}\text { The community performed } \\
\text { demonstrations in a subtle manner }\end{array}$ & 67 & 34 & 0 & 0 & 404 & 307 & 75.99 & $\begin{array}{l}\text { Strongly } \\
\text { agree }\end{array}$ \\
\hline $\begin{array}{c}\text { The community staged a radical } \\
\text { demonstration }\end{array}$ & 25 & 76 & 0 & 0 & 404 & 177 & 43.81 & Disagree \\
\hline $\begin{array}{l}\text { The occurrence of physical clashes } \\
\text { between conflicting parties }\end{array}$ & 2 & 3 & 85 & 11 & 404 & 135 & 33.42 & Disagree \\
\hline
\end{tabular}

Information:

Interpretation of Calculation Score, numbers 0\% - 24.99\% Strongly Disagree (SD), 25\% - 49.99\% Disagree (D), 50\% - 74.99\% Agree (A) and 75\% - 100\% Strongly Agree (SA)

agreed and 5 strongly agreed. The result of the formula index is $54.95 \%$, in the "Agree" category. This result shows that the majority, namely 66 respondents, do not agree that the community often receives terror from the company. This fact is confirmed by the index formula value of $54.95 \%$ which is a sign that the results are correct and factual.

The community often receives threats from companies. The results of the respondents showed that 16 respondents strongly disagreed, 50 disagreed and 35 agreed. The result of the formula index is $54.70 \%$, which is in the "Agree" category. This result shows that the majority, namely 66 respondents, do not agree that the community often receives threats from companies. This fact is confirmed by the index formula value of $54.70 \%$ which is a sign that the results are correct and factual.

The mining activity of iron ore has caused tensions between residents and the company. The results of respondents showed 9 respondents strongly disagreed, 18 disagreed, 63 agreed and 11 strongly agreed. The result of the formula index is $68.81 \%$, which is in the "Agree" category. This result shows that the majority, namely 74 respondents, agreed that iron ore mining activities caused tensions between residents and the company. This fact is confirmed by the index formula value of $54.70 \%$ which is a sign that the results are correct and factual.

The mining activity of iron ore causes tension between residents and the government. The results of respondents showed 6 respondents strongly disagreed, 30 disagreed, 61 agreed and 4 strongly agreed. The result of the formula index is $65.59 \%$, which is in the "Agree" category. This result shows that the majority, namely 65 respondents, agreed that iron ore mining activities caused tensions between residents and the government. This fact is confirmed by the index formula value of $68.81 \%$, which is a sign that the results are correct and factual.

The mining activity of iron ore causes the community to take subtle actions against / strikes. The results of the respondents showed that 2 respondents strongly disagreed, 6 disagreed, 35 agreed and 58 strongly agreed. The result of the formula index is $86.88 \%$, which is in the "Strongly Agree" category. This result shows that the majority, namely 93 respondents, 
agreed that the iron ore mining activity caused the community to carry out refusal actions in subtle ways/strikes. This fact is confirmed by the index formula value of $86.88 \%$ which is a sign that the results are correct and factual.

The mining activity of iron ore causes the community to carry out subtle demonstrations (long march, etc.). The results of the respondents showed that 67 respondents strongly disagreed and 34 disagreed. The result of the formula index is $75.99 \%$, which is in the "strongly agree" category. This result shows that the majority, namely 96 respondents, agreed that iron ore mining activities caused the community to carry out demonstrations in a smooth manner (long march, etc.). This fact is confirmed by the index formula value of $75.99 \%$ which is a sign that the result is correct and factual.

The mining activities of iron ore led to radical demonstrations (violence, vandalism, etc.). The results of the respondents showed that 25 respondents strongly disagreed, 76 disagreed, 0 agreed and 0 strongly agreed. The result of the index formula is $43.81 \%$, which is in the "Disagree" category. These results indicate that the majority, namely 101 respondents, do not agree that iron ore mining activities have caused the community to carry out radical demonstrations (violence, vandalism, etc.). This fact is confirmed by the index formula value of $43.81 \%$ which is a sign that the results are not factual.

Iron ore mining activities cause physical clashes between conflicting parties. The results of the respondents showed that 2 respondents strongly disagreed, 3 disagreed, 85 agreed and 11 strongly agreed. The result of the index formula is $33.42 \%$, which is in the "disagree" category. These results indicate that the majority, namely 101 respondents, do not agree that iron ore mining activities cause physical clashes between conflicting parties. This fact is confirmed by the index formula value of $33.42 \%$ which is a sign that the results are not factual.

The quantitative data shows facts that confirm the qualitative findings data. The details are as follows: The quantitative findings show that 54 respondents confirmed their agreement that iron ore mining activities caused unrest among residents. This finding is factual because the index value is $64.36 \%$. This finding is in line with the qualitative findings expressed by BB:

"...We need to solve the problem with the
company by sitting together to find a solution, but if we can't get the red thread, we need to solve the custom of the Bugis Bone where the end of the badik or the machete is talking...."(BB)

The quantitative findings show that 55 respondents confirmed their agreement that iron ore mining activities caused tensions between residents. This finding is factual because the index value is $64.85 \%$. This finding is in line with the qualitative findings expressed by SP:

"...The weakness of the movement so far is because existing community groups are difficult to unite..." (BB)

The quantitative findings show that 66 respondents confirmed their disapproval that the public often receives terror from the company. This finding is factual because the index value is $54.95 \%$. This finding is in line with the qualitative findings that none of the informants stated that they were terrorized by the company.

The quantitative findings show that 66 respondents confirmed their disagreement that the community often receives threats from companies. This finding is factual because the index value is $54.70 \%$. This finding is in line with the qualitative findings that none of the informants stated that they had received threats from the company.

The quantitative findings show that 74 respondents confirmed their agreement that iron ore mining activities caused tensions between residents and the company. This finding is factual because the index value is $68.81 \%$. These findings are in line with the qualitative findings expressed by Th and RKP:

“...The existing conflicts are regarding land acquisition, environment, community empowerment. Many company promises are not realized..." (Th)

"...The form of conflict that occurs is the problem of land acquisition. The land that had been cleared by the company was then claimed again by a group of people as their land..." (RKP)

The quantitative findings show that 65 respondents confirmed their agreement that iron ore mining activities caused tensions between residents and the government. This finding is factual because the index 
value is $65.59 \%$. This finding is in line with the qualitative findings expressed by BB:

"...The government is silent as if they do not know the community's problems with the company..." (BB)

The quantitative findings show that 93 respondents confirmed their agreement that iron ore mining activities caused the community to carry out subtle actions of resistance/strikes. This finding is factual because the index value is $86.88 \%$. These findings are in line with the qualitative findings expressed by $\mathrm{NI}$ :

"...The existence of mining activities is one of our hopes in Bontocani, especially if the mining company can run well, there are jobs and a new economic vortex. However, the facts that exist from the various companies that have entered Bontocani have not had the expected impact. Only a handful of people feel. The community around the mine, the pros, and cons of mining activities, may be due to poor socialization. Not all companies that enter communicate with the community, this is the main problem with unstable socialization. The community in the mining area is haunted by extraordinary suspicion. The most pronounced impact was that public roads were disturbed when PT. Sindo Mandiri carries out production activities and uses axle roads, many accidents occur because truck drivers chasing routes every day do not care about other users. Especially for agricultural and retail traders, in some villages, their supply is hampered by these activities. The most dangerous disadvantages are that the excavation distance from residents' houses is only around $30 \mathrm{~m}$, the noise of heavy equipment, and chemical impacts threaten the health of residents. Social jealousy also arose because those involved were only the residents who were compiled in question, was that according to the procedure or not? one thing is certain that this jealousy is based on their lack of understanding of the rights and obligations of the community by having companies enter. Currently, there is no positive progress in resolving conflicts between residents and companies, moreover, company activities are also at a standstill. There is one thing that is still under control, namely the Marble Mine in Mattirowalie Village because the village government and residents are still united until now. Even then, the activity has not yet started..." (NI)

The quantitative findings show that 96 respondents confirmed their agreement that iron ore mining activities caused the community to carry out soft demonstrations (long marches, etc.). This finding is factual because the index value is $75.99 \%$. These findings are in line with the qualitative findings expressed by the RKP:

“...Several companies have entered here. First, PT. MMI entered exploration. Both PT. Cipta Pes also only reached the exploration stage. Third PT. APB and this company were exploited before being closed. Before researching community outreach companies. The presence of the company provides great benefits to the people of Pake hamlet. There must be losses. We have experienced many benefits with the company, including repairing road infrastructure, recruiting workers, and compensating the felled plants. While the disadvantage is that there are people who do not agree with the company, so groups are formed. We think that Pake hamlet residents have no problem. Those in conflict are residents who claim that the mining location belongs to them and until now there has been no meeting point between the company and the residents who claim it...."(RKP)

The quantitative findings show that 101 respondents confirmed their disagreement that iron ore mining activities caused the community to carry out radical demonstrations (violence, destruction, etc.). This finding is factual because the index value is $75.99 \%$ because in qualitative observations and interviews there is no fact that there are demonstrations of a radical nature.

The quantitative findings show that 101 respondents confirmed their disagreement that iron ore mining 
activities led to physical clashes between conflicting parties. This finding is factual because the index value is $91.58 \%$ because, in qualitative observations and interviews, there are no facts about physical clashes between conflicting parties.

From the point of view of Communicative Action Theory, social disconnectivity occurs because 1) Domination of one or more groups (company and government) over other groups (residents around the mine 2) Egalitarian communication does not occur because of domination. 3) Personal and group behavior based on instrumental ratios which make social behavior concerned only with the interests of the group. 4) This instrumental ratio-based behavior triggers behavior that is considered by one group to be bad, for example, violations of local wisdom of the local community and mining activities that damage the environment of residents around the mine.

\section{CONCLUSION}

The conclusions of this study are 1. Social dissectionality in the vicinity of the mine occurs due to the company's greed in exploring natural resources which are exacerbated by weak government control that does not favour the interests of the community around mining, 2. The social process that determines the incidence of social disconnection of mining actors in action. The dominant communication is only carried out by the company and the government without involving the community in a participatory manner. 3. Harmonization of relations between mining actors can be achieved by developing communicative actions based on local wisdom through building a joint consensus between the company, government and the community.

The practical implications of this research are to avoid industrial conflicts among mining actors, to position ecological and socio-cultural impacts as the basis for environmental exploration for mining, and to provide emancipation pathways for the community to improve their welfare.

\section{REFERENCES}

Arowoshegbe, Amos O, Uniamikogbo Emmanuel, and Atu Gina. 2016. "Sustainability and Triple Bottom Line: An Overview of Two Interrelated Concepts." Igbinedion University Journal of Accounting 2(16): 88-126.

Cornwell, Erin York, and Linda J Waite. 2009a. "Measuring Social Isolation Among Older Adults Using Multiple Indicators from the NSHAP Study." Journals of Gerontology Series B: Psychological Sciences and Social Sciences 64(suppl_1): i38-46.

https://doi.org/10.1093/geronb/gbp037 2009b. "Social Disconnectedness, Perceived Isolation, and Health Among Older Adults." Journal of Health and Social Behavior 50(1): 31-48. https://doi.org/10.1177/002214650905000103

Creswell, John W, and Vicki L Plano Clark. 2017. Designing and Conducting Mixed Methods Research. Sage publications.

Eckhard, Jan. 2021. "Social Isolation as a Consequence of Transitions in Partner Relationships: How Formations and Endings of Partner Relationships Affect the Risk of Social Disconnectedness." Journal of Family Research 33(1): 2271.

https://doi.org/10.20377/jfr-367

Eraslan-Capan, Bahtiyar. 2016. "Social Connectedness and Flourishing: The Mediating Role of Hopelessness." Universal Journal of Educational Research 4(5): 933-40. https://doi.org/10.13189/ujer.2016.040501

Felisia, and Amelia Limijaya. 2014. "Triple Bottom Line Dan Sustainability." Bina Ekonomi Majalah IImiah Fakultas Ekonomi Unpar 18(1): 14-27. https://doi.org/10.26593/be.v18i1.827.\%25p

Firouzeh, Taghikhah, Daniel Jay, and Mooney Grant. 2017. "Profit, Planet and People in Supply Chain: Grand Challenges and Future Opportunities." In Proceedings of the 25th European Conference on Information Systems (ECIS) 5-10 June, Guimarães, Portugal: AIS Electronic Library (AISeL), 12991313. http://hdl.handle.net/10545/625340.

Greene, Jennifer C, Valerie J Caracelli, and Wendy F Graham. 1989. "Toward a Conceptual Framework for Mixed-Method Evaluation Designs." Educational evaluation and policy analysis 11(3): 255-74. https://doi.org/10.3102/01623737011003255

Guilcher, Sara J T et al. 2021. "An Examination of Objective Social Disconnectedness and Perceived Social Isolation Among Persons With Spinal Cord Injury/Dysfunction: A Descriptive Cross-Sectional Study." Disability and rehabilitation 43(1): 69-75. https://doi.org/10.1080/09638288.2019.1616328

Irwandi, and Endah Ratnawaty Chotim. 2017. "Analisis Konflik Antara Masyarakat, Pemerintah Dan Swasta." JISPO Jurnal IImu Sosial dan IImu Politik 7(2): 24-42. https://journal.uinsgd. ac.id/index.php/jispo/article/view/2414.

Iwan. 2016. "Menelaah Teori Kritis Jürgen Habermas." Edueksos: Jurnal Pendidikan Sosial \& Ekonomi 3(2): 145-65. https://www.syekhnurjati.ac.id/jurnal/index.php/edueksos/arti cle/view/360/315.

Jamil, Muh., and Teo Reffelsen. 2020. Terus Meligitimasi Lubang Kematian: Kertas Kebijakan Reklamasi Lubang Tambang Di Indonesia. Jakarat: Jaringan Advokasi Tambang (JATAM).

Kambewa, Emma Verah. 2007. "Balancing the People, Profit and Planet Dimensions in International Marketing Channels: A Study on Coordinating Mechanisms in the Nile Perch Channel from Lake Victoria." Wageningen University. https://library.wur.nl/WebQuery/wurpubs/fulltext/121878.

Lee, Richard M, Matthew Draper, and Sujin Lee. 2001. "Social Connectedness, Dysfunctional Interpersonal Behaviors, and Psychological Distress: Testing a Mediator Model." Journal of counseling psychology 48(3): 310. https://doi.org/10.1037/0022-0167.48.3.310

Munauwarah. 2016. "Konflik Kepentingan Dalam Perebutan Lahan Pertambangan Di Kabupaten Luwu Timur Antara Masyarakat Adat To Karunsi'e Dengan PT. Vale Indonesia." The POLITICS: Jurnal Magister IImu Politik Universitas Hasanuddin 2(2): 132-46.

Qurbani, I D. 2020. "Mining Conflict Resolution: A Case Study of Iron Sand Mining in Lumajang, Indonesia." In Proceedings of the First Brawijaya International Conference on Social and Political Sciences, 26-28 November, 2019, Malang, East Java, Indonesia: BSPACE.

https://doi.org/10.4108/eai.26-11-2019.2295155 
Tashakkori, Abbas, Charles Teddlie, and Charles B Teddlie. 1998. 46 Mixed Methodology: Combining Qualitative and Quantitative Approaches. Sage.
Widyanta, A B. 2013. "Sampyuh: Genealogi Konflik Industri Ekstraktif Di Lanskap Masyarakat Agraris." Jurnal Pemikiran Sosiologi 2(2): 87-106.

https://doi.org/10.22146/jps.v2i2.30018

(C) 2021 Samanlangi et al.; Licensee Lifescience Global.

This is an open access article licensed under the terms of the Creative Commons Attribution Non-Commercial License (http://creativecommons.org/licenses/by-nc/3.0/) which permits unrestricted, non-commercial use, distribution and reproduction in any medium, provided the work is properly cited. 